\title{
The Correlation between the Anxiety of the Family Members of the Patients Referring to the Emergency Department and Their Views on the Communication Skills of Nurses
}

\author{
Mahnaz Seyedoshohadaee ${ }^{1}$, Mina Ahmadi ${ }^{2}$, Hamid Haghani ${ }^{3}$
}

\begin{abstract}
Background \& Aims: Emergency departments (EDs) are the most challenging ward concerning patient care. The hospitalization of a family member in the hospital, especially in ED, increases anxiety and psychological problems in other members of the family. Given the emergency patients' need for immediate and special care, understanding their problems in the ED is crucial to provide favorable services and increase satisfaction in these individuals. Effective communication and intrapersonal skills are the basic principles for the provision of high-quality care. Therefore, establishing effective communication between the healthcare team and family members of the patient is significantly vital to provide safe care and prevent damage to the patient. This is specifically important in stressful hospital wards (e.g., Eds). The way nurses interact with patients and their companions play an important role in the control and management of their anxiety levels. In addition, favorable nurses' communication with patients and their families could contribute to gathering the required information and proper management of the treatment process. The present study aimed to determine the relationship between the anxiety of emergency patients' family members with their views on nurses' communication skills.

Materials \& Methods: This was a descriptive, correlational and cross-sectional study performed on 263 family members of patients referring to the Eds of two selected training healthcare centers affiliated with Iran University of Medical Sciences in 2019. The participants were selected by continuous sampling based on the inclusion criteria, which included age above 18 years, being literate, no history of psychological disorders or use of psychiatric medications (based on self-report), and being a first-degree relative (mother, father, sister, brother, child, spouse). The sample size was estimated at 263 to determine the sample size at $95 \%$ confidence level and $90 \%$ test power assuming that the correlation coefficient between the relationship between the nurse and anxiety in the patients' families was at least 0.2 , so that this correlation is considered statistically significant. Data were collected using a demographic characteristics questionnaire (age, gender, level of education, marital status, economic status, occupational status, kinship, insurance status, and triage level), the health care climate questionnaire (HCCQ), and Beck anxiety inventory (BAI). Data analysis was performed in SPSS version 16 using Pearson's correlation coefficient, analysis of variance, and the Kruskal-Wallis test. In addition, a P-value of 0.05 was considered statistically significant.

Results: In this study, the mean age of the participants was $42.92 \pm 11.64$ years. In terms of gender, $56.3 \%$ of the participants were male and the rest were female. Regarding the level of education, the highest frequency was related to below diploma degrees $(40.7 \%)$. In addition, poor $(48.3 \%)$ and moderate $(46.8 \%)$ economic states had the highest frequency, respectively. The majority of the participants were married $(75.3 \%)$, and most of the companions were patients' children (58.2\%) and spouse $(22.1 \%)$. Moreover, $89.4 \%$ of the patients had basic insurance coverage. Cardiovascular disease with $44.9 \%$ was the most common cause of referral, and the ratio of patients' triage level was almost equal. According to the results, the score of nurses' communication skills in EDs was reported to be poor from the perspective of patients' companions $(36.74 \pm 7.3)$. In addition, the results obtained from the BAI indicated that most family members $(75.3 \%)$ had a mild anxiety level, whereas $18 \%$ and $6.8 \%$ of them had moderate and severe anxiety levels, respectively. Furthermore, the total anxiety score of the
\end{abstract}

\footnotetext{
1. Instructor, Nursing Care Research Center, Department in Internal-Surgical Nursing, School of Nursing and Midwifery, Iran University of Medical Sciences, Tehran, Iran

2. MS in Emergency Department Nursing, School of Nursing and Midwifery, Iran University of Medical Sciences, Tehran, Iran (Corresponding author) Tel: 09224501760 $\quad$ Email: mina.ahmadi3388@gmail.com

${ }^{3}$. Instructor, Department of Biostatistics, School of Health, Iran University of Medical Sciences, Tehran, Iran
} 
companions was estimated at $13.25 \pm 14.16$, which demonstrated their low anxiety level. Pearson's correlation coefficient results were indicative of no significant relationship between nurses' communication skills and their dimensions with anxiety levels in patients' family members. In addition, the analysis of patients' family members' anxiety based on demographic characteristics showed a significant relationship between anxiety and level of education $(\mathrm{P}=0.039)$, economic status $(\mathrm{P}=0.033)$, and kinship $(\mathrm{P}=0.001)$. Moreover, the mean anxiety score was significantly higher in children of patients, compared to spouses $(\mathrm{P}=0.008)$. Furthermore, there was a significant relationship between the triage level of patients and the anxiety level of companions of patients $(\mathrm{P}<0.001)$. In addition, anxiety was significantly lower in family members of patients with a triage level of three and higher, compared to patients with a triage level of one $(\mathrm{P}=0.012)$ and two $(\mathrm{P}<0.001)$.

Conclusion: According to the results, nurses had unfavorable communication skills from the perspective of patients' family members. In addition, a mild anxiety level was observed in most family members of emergency patients. Despite a lack of a significant relationship between the anxiety of family members and their views on nurses' communication skills, it seems that the poor communication skills of nurses from the perspective of the patient's family member need special attention. As the first service providers that clients encounter, nurses are responsible for the perception of family members of patients about healthcare services. Therefore, it seems necessary to more focus on factors affecting the effective communication between nurses and companions of patients in hospitals. In addition, attempts should be made to remove or reduce communication issues through proper plans and measures. The results of the present study can be used to plan for improving nurses' communication skills by designing and implementing in-service training or other incentive mechanisms to increase nurses' communication skills as well as managing the anxiety of patients and their companions.

\section{Keywords: Anxiety, Family, Emergency Department, Communication Skills, Nurse}

\section{Conflict of Interest: No}

How to Cite: Seyedoshohadaee M, Ahmadi M, Haghani H. The Correlation between the Anxiety of the Family Members of the Patients Referring to the Emergency Department and Their Views on the Communication Skills of Nurses. Iran Journal of Nursing. 2019; 32(119):87-98.

Received: 21 May 2019

Accepted: 21 Aug 2019 


\title{
ارتباط اضطراب اعضاى خانواده بيماران مراجعه كننده به بخشهاى اورزانس با ديدكاه آنان در مورد مهارتهاى ارتباطى بر ستاران
}

\author{
مهناز سيدالشهدايى'، مينا احمدى '، حميد حقانى
}

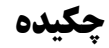

زمينه و هدف: بسترى شدن يكى از اعضاى خانواده در بيمارستان به ويزه در بخش اورثانس باعث ايجاد اضطراب و مشكلات روحى و روانى در ديكر

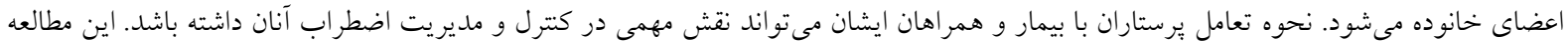

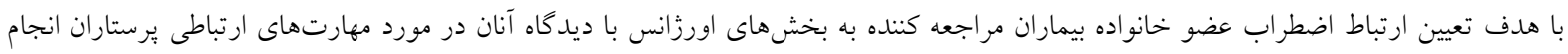

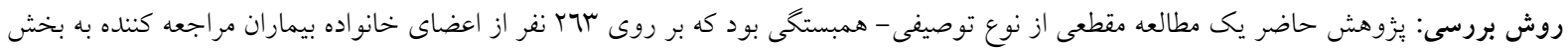

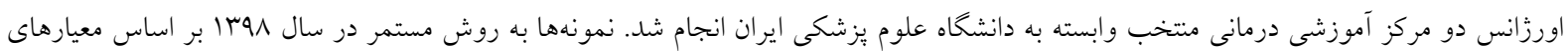

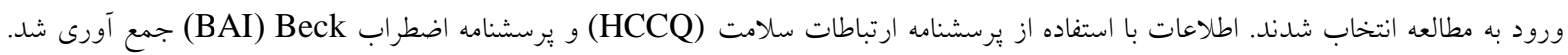

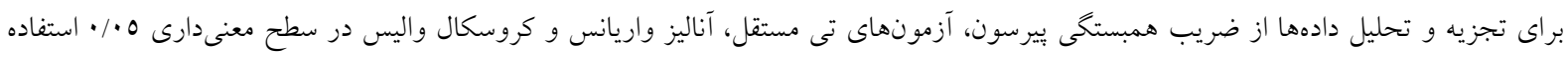

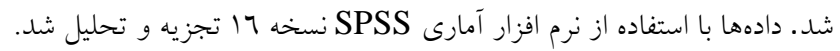

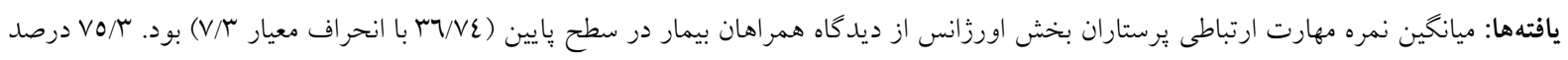

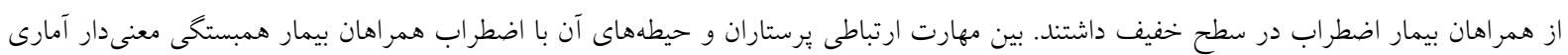

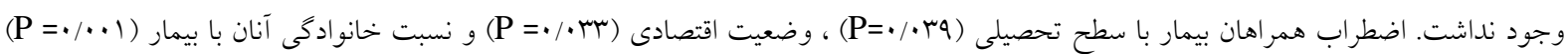

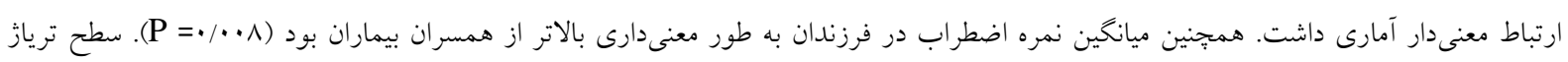

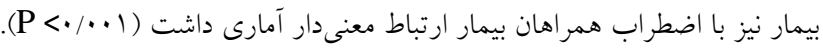

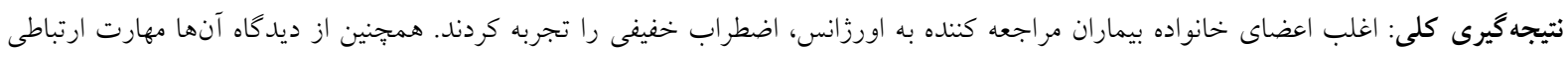

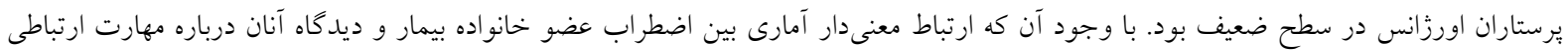

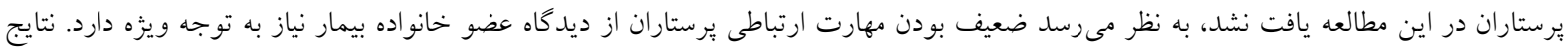

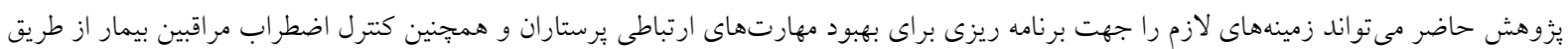
آموزشهاى ضمن خدمت و يا ساير مكانيسمهاى تشويقى فراهم كند.
\end{abstract}

كليد وازهها: اضطراب، خانواده، بخش اورزانس، مهارت ارتباطى، يرستار تعارض منافع: ندارد

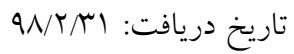

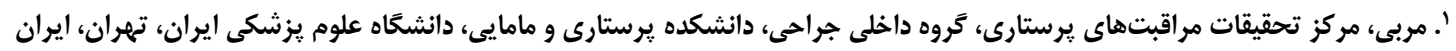

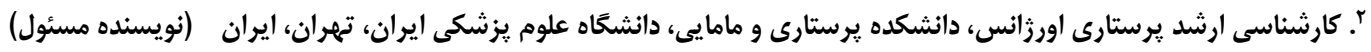
Email: mina.ahmadi3388@gmail.com

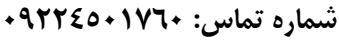

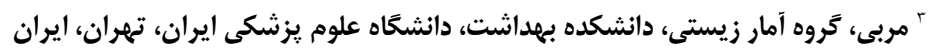




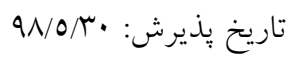

فردى اصول يايهاى و اصلى براى ارايه خدمات مراقبت با كيفيت است(0) ارتباط مؤثر بين تيم درمان و اعضاى لرى خانواده بيمار به منظور فراهم كردن يك مراقبت ايمن و

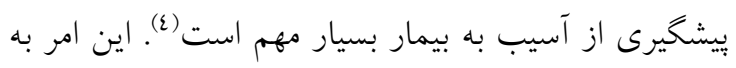
ويزه در بخشهاى يرتنش بيمارستان مانند اورزانس براى ارايه خدمات مراقبت با كيفيت بسيار مهم است. بسترى شدن يكى از اعضاى خانو اده در بيمارستان به ويزه در بخش اورزانس باعث ايجاد اضطر اب و مشكلات روانى

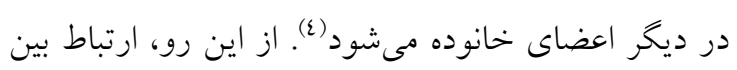

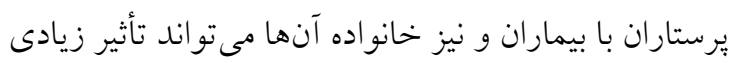
در كنترل و مديريت اضطراب آنان و به علاوه ارتقاء بهبود مر اقبتهاى يرستارى داشته باشد (ع). اضطر اب مفهوم مبهم

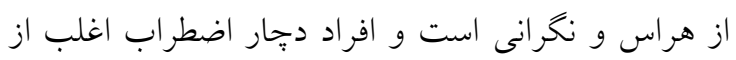
نظر روانى نسبت به آينده نامطمئن و نخران هستند. به إنه خصوص اخر اين اضطراب در بيماران بسترى در بخش هاى يرتنشى مانند اورزانس باشد، اضطراب مضاعف مى شود. اضطراب در افرادى كه در تصميم گيرى بيمارشان نقش دارند به طور معنىدارى بيشتر است. همجنين، عدم بر آورده شدن برخى نيازها در افر اد خانو اده باعث اضطراب

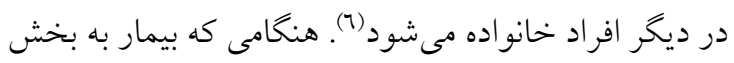

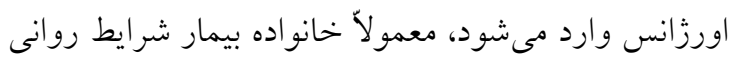

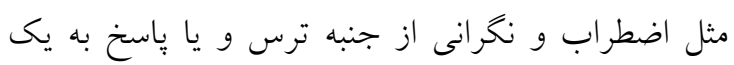
تهايد ناشناخته كه يك واكنش عمومى در شرايط برتنش مثل بيمارى يا وضعيتهاى تهلديدكننده حيات است، را تجربه مى كنند (v). اعضاى خانو اده بيمار در حمايت از بيمار نقش مهمى را به عهله دارند و باعث ياسخ درمانى مطلوب در بيمار مىشوند. اما وقتى اضطراب در اعضاى خانواده زياد باشد ممكن است نتوانند نقش حمايتى مؤثرى داشته

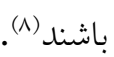

نتايج يزوهش lamiani و همكار ان حاكى از وجود ضعف در زمينه برقرارى ارتباط برستاران با بيماران و خانو ادههاى آنها است(9). در مطالعه زارعى و همكاران كه به منظور بررسى اضطراب در عضو خانو اده بيماران بسترى در بخش

\section{مقلدمه}

بخش اورزانس يكى از بخشهاى جالش بر انخيز براى بيمار و خانواده آنها است و منجر به بروز اضطراب و مشكلات روحى و روانى براى آنها مى گردد (1). با وجود اين كه تمركز اصلى فعاليت در اين بخش نجات جان و درمان بيماران

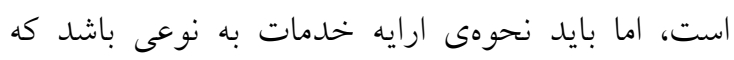
رضايت بيماران و خانواده آنان را نيز فراهم آورد. در دهه اخير بخشهاى اورزانس با افزايش مراجعين روبرو بوده است كه معلول عو امل متعددى است (Y). بيمارانى كه به اين بخش مراجعه مىنمايند از نظر جسمانى در حالت بحرانى

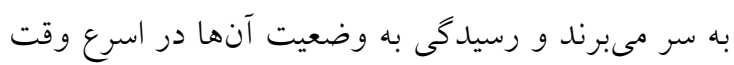

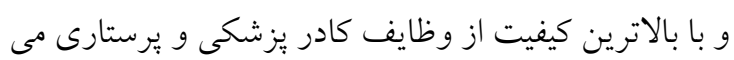
باشد. اولين تجربه بيماران از بيمارستان اغلب به بخش اورزانس مربوط مىشود. از آن جايى كه بيماران اورزانسى نياز به درمان و مراقبت فورى و خاص دارند، درى مشكل بيماران در بخش فوريتها براى ارائه خدمات مطلوب و كسب رضايت آنان ضرورى است(r). نظر به اين كه تقريباً TA درصد مراجعان به بخش اورزانس بعد از اقدامات اوليه به بخشهاى مختلف بيمارستان منتقل و در آنجا بسترى مىشوند، به بخش اورزانس بايد به عنوان منبع حيات بيمارستان نخاه كرد. بيمارانى كه به بخش اورزانس مراجعه

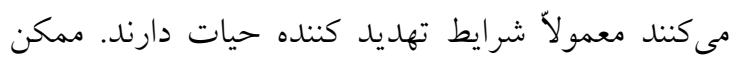
است اختلال هوشيارى داشته باشند و كاركنان اطلاعات زيادى در رابطه با تاريخهه دارويى و بيمارى آنها نداشته باشند. با اين وجود، يرستار بايد تلاش كند با همان

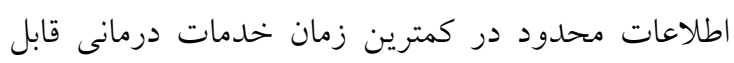
قبولى را ارايه دهد. ارتباط مطلوب يرستار با بيمار و خانواده وى مىتواند نقش مهمى را در كسب اطلاعات مورد نياز و مديريت بهتر درمان و مراقبت ايفا نمايد معا. ارتباط، يكى از نقش هاى كليدى يرستاران است. يك ارتباط

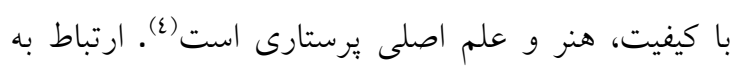
معنى تبادل اطلاعات، تجارب زندگى، احساسات، افكار، عقايد و دانش مىباشد. ارتباط مؤثر و مهارتهاى درون 
دسترس بودن و سهولت كردآورى داده انتخاب شدند.

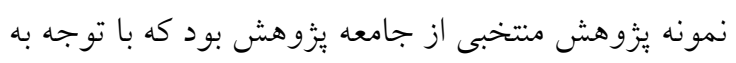

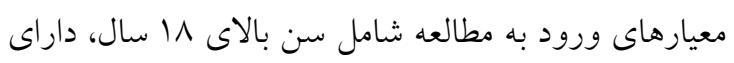

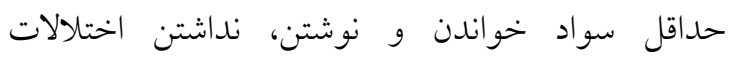

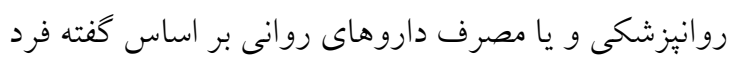

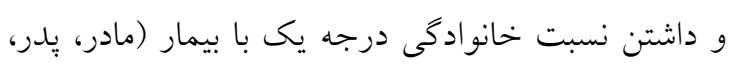

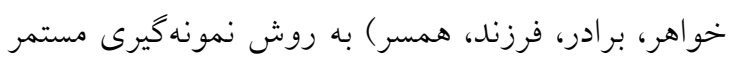

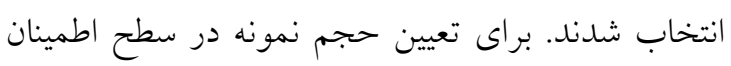

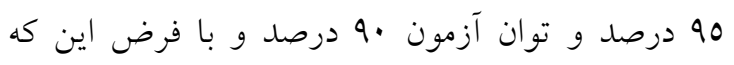
ضريب همبستكى بين رابطه برستار و اضطراب در خانواده

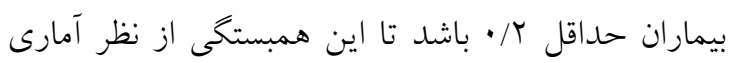
معنى دار تلقى شود، تعداد حجم نمونه ساحب نفر محاسبه

در اين مطالعه ابزار جمع آورى اطلاعات شامل فرم

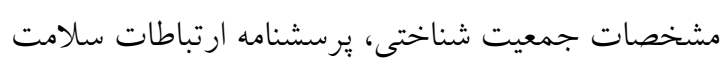
و (Healthcare Communication Questionnaire) يرسشنامه اضطراب BAI) Beck) بود. فرم مشخصات جمعيت شناختى شامل سئو الات مربوط به سن، جنسيت،

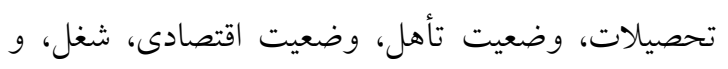

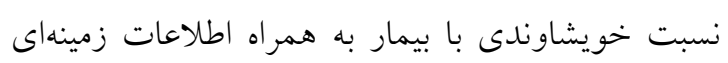
نظير وضعيت بيمه بيمار و سطح ترياز بيمار (اطلاعات

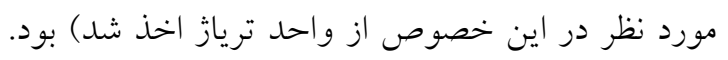

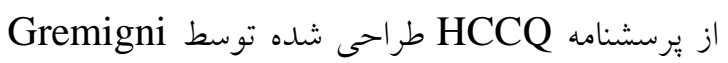

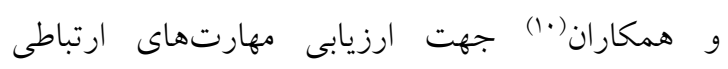

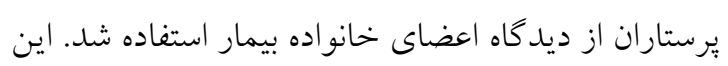
يرسشنامه داراى سا كويه بود و از طيف ليكرت ينج درجها

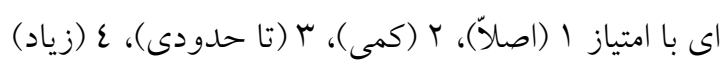

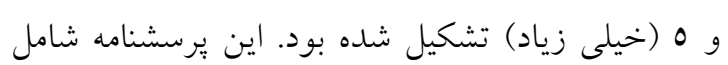
جهار حيطه حل مسئله (ع سئوال)، احترام (ع سئوال)،

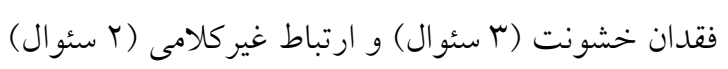

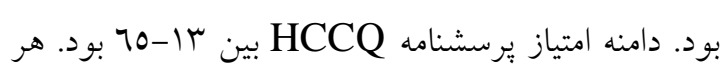
جقدر نمره كسب شده بالاتر از ميانه (•ع) بود، مهارت

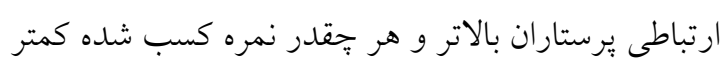

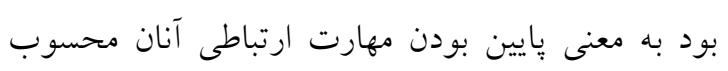

اورزانس انجام شد، نتايج نشان داد كه اغلب اعضاى

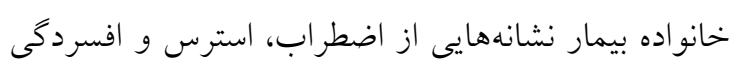

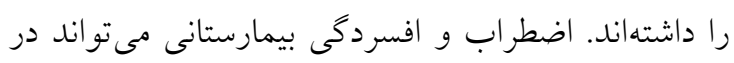
بيماران يا اعضاى خانواده بيمار اتفاق بيفتد. از جمله عناصرى كه مىتوانند منجر به اضطراب در عضو خانو اده

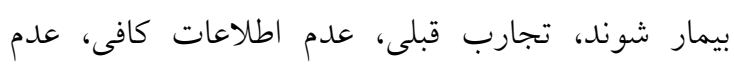

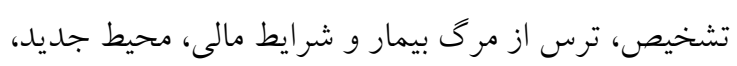

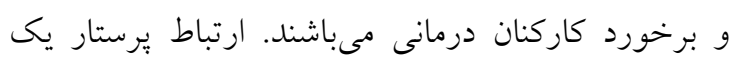
نقش مهم در كنترل اضطراب عضو خانواده بيمار دارد.

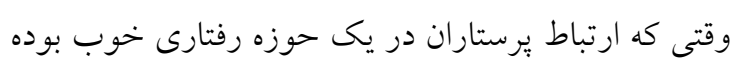

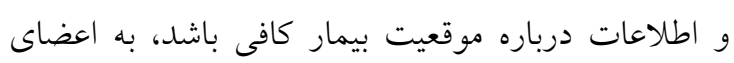

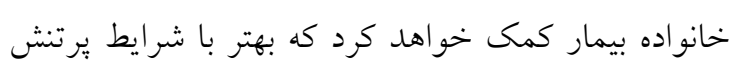
بيمار كنار بيايند (A). با توجه به موارد فوق، افزايش دانش درباره مهارتهاى بياى يناء

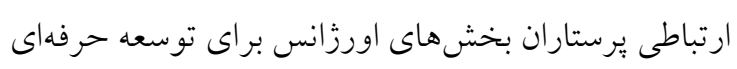

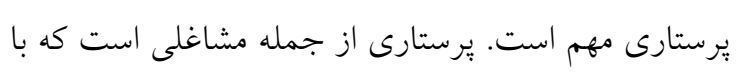

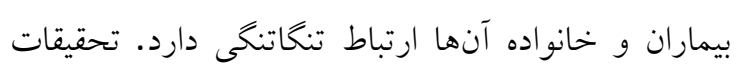
نشان مىدهد كه محتواى ارتباط برستار با اعضاى خانو اده بيمار به خوبى شناخته نشده و تحقيقات اندكى در اين زمينه

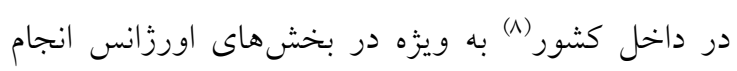

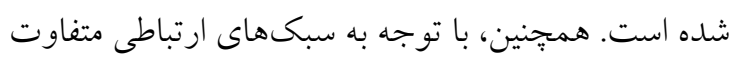

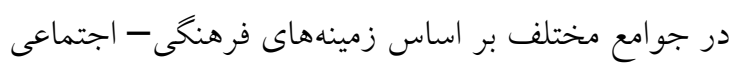

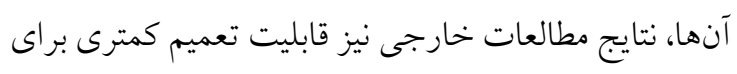

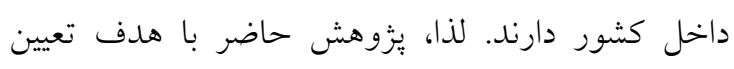

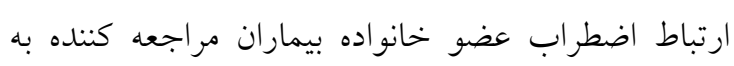

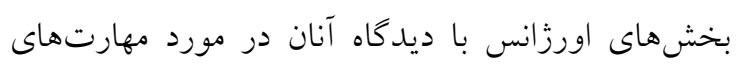

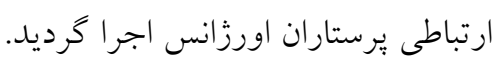

\section{روش بررسى}

ئزوهش حاضر يك مطالعهى مقطعى از نوع توصيفى - مدنى

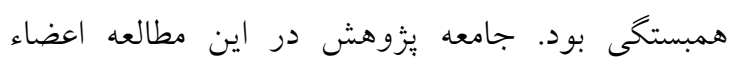

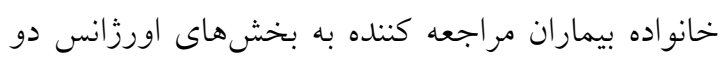

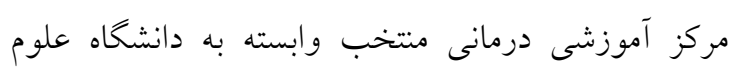

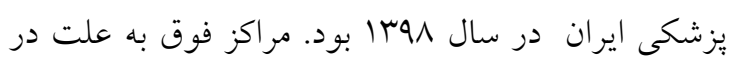


يُزوهش حضور يافته و ضمن معرفى خود و توضيحات

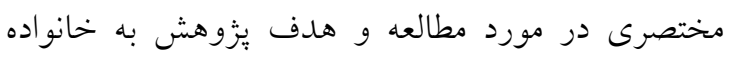

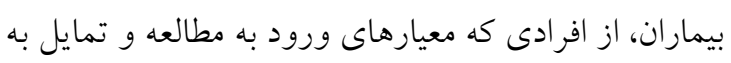

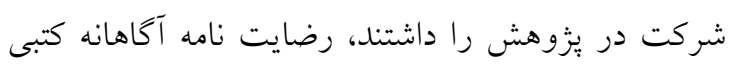

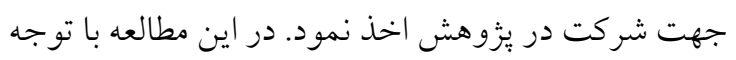
به سطح تحصيلات يايين اغلب واحدهاى يزوهش احتمال

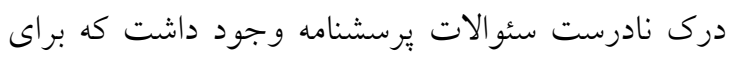
بيشكيرى از اين مشكل به تمام شركت كنند كان توضيحات

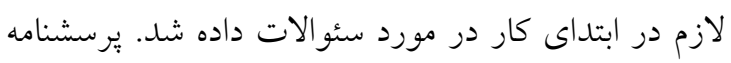

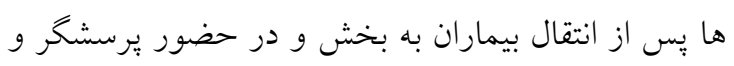

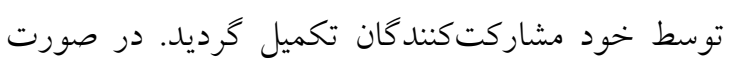

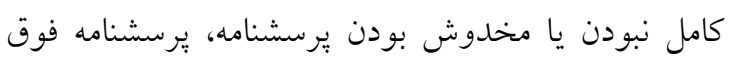

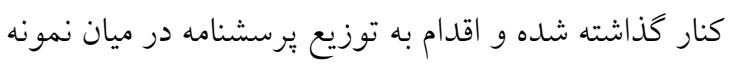

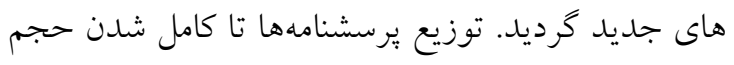

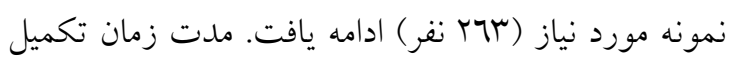

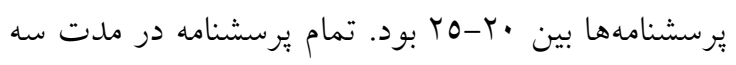

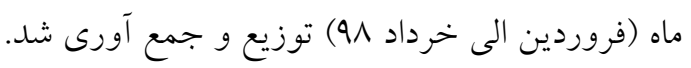

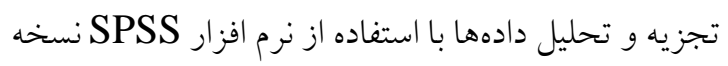

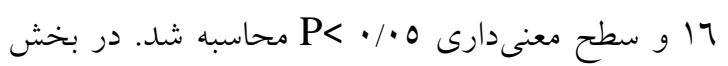
آمار توصيفى از جداول توزيع فراوانى براى متغيرهاى كيفى يُزوهش و شاخصهاى عددى كمينه، بيشينه،

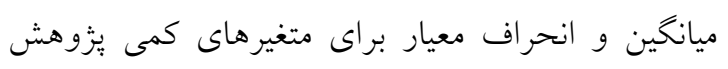

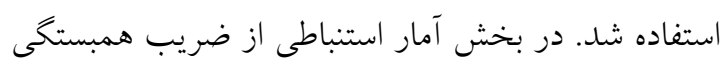
بيرسون براى بررسى همبستخى بين اضطراب با مهارت

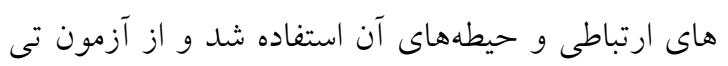

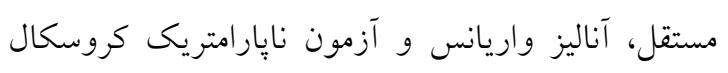

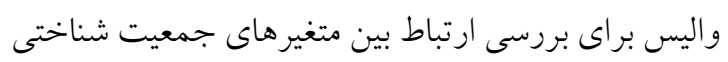
با متغير اضطراب استفاده شد.

يافته ها تجزيه و تحليل دادهها در مورد rآr نفر از عضو خانواده

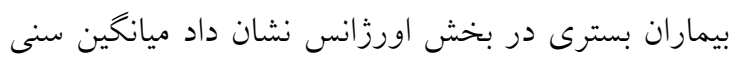

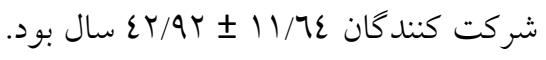

شد (1). يرسشنامه اضطراب Beck نيز جهت تعيين سطح

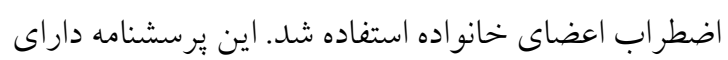

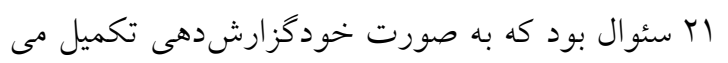

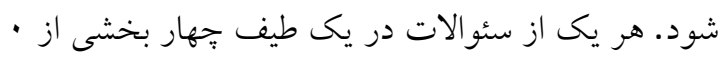

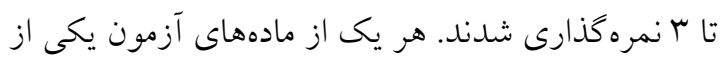

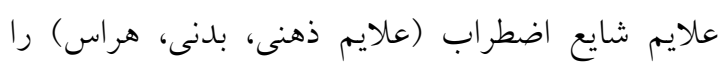

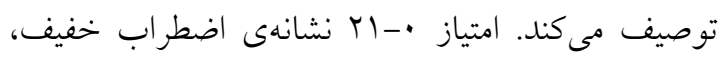
r r Y r نشان دهندهى اضطر اب متوسط و بالاى حس نشانه اضطر اب شديد بود (Ir).

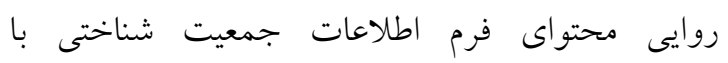

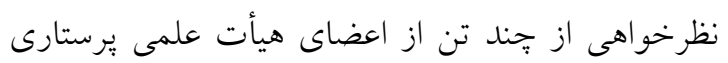

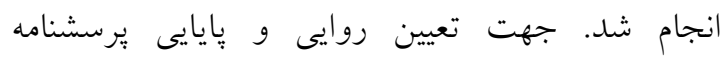

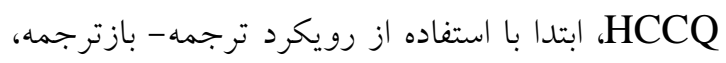

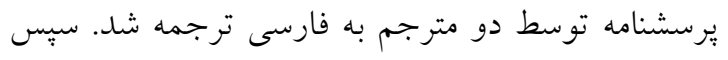
متن ترجمه شده توسط دو متخصص دو زبانه ديخر به

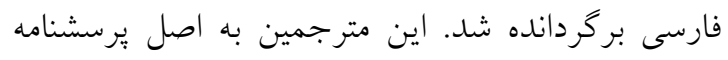

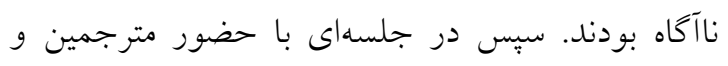

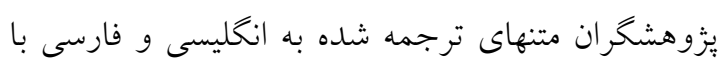

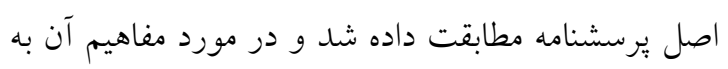

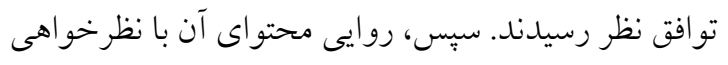

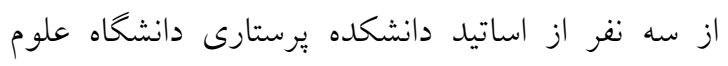

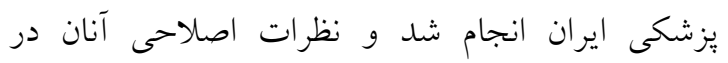

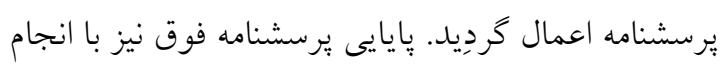

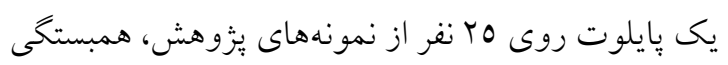

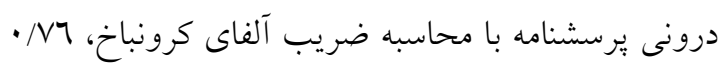

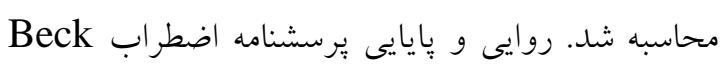

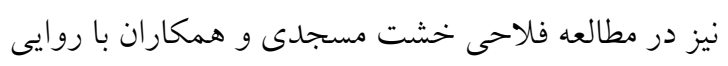

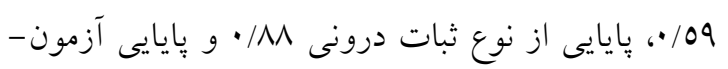

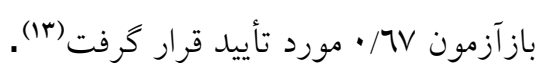

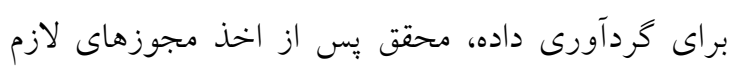

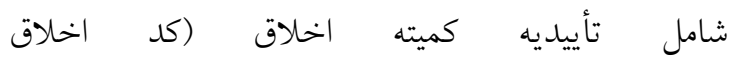

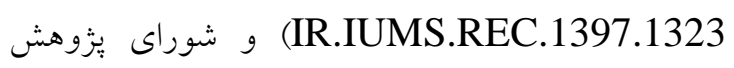
دانشخاه علوم يُزشكى ايران و تهيه معرفى نامه، در محيط 
جدول شماره ا: توزيع فراوانى مشخصات فردى عضو خانواده بيماران مراجعه كننده به بخش هاى اورزانس و ارتباط اضطراب با آنها

\begin{tabular}{|c|c|c|c|c|c|c|}
\hline \multirow[t]{2}{*}{ نتيجه آمارى } & \multicolumn{2}{|c|}{ اضطر اب } & \multirow[t]{2}{*}{ درصد } & \multirow[t]{2}{*}{ فراوانى } & \multirow[t]{2}{*}{ مشخصات فردى } & \\
\hline & انحراف معيار & ميانخين & & & & \\
\hline \multirow{6}{*}{$* \mathrm{P}=\cdot / \cdot \wedge$} & $11 / 70$ & $11 / \cdot 9$ & $1 T / 0$ & r & كمتر از •rr & \multirow{6}{*}{ سن (سال) } \\
\hline & $11 / T r$ & $\mid r / 01$ & ro/9 & $u$ & $r \cdot-r q$ & \\
\hline & 17/ 17 1 & $10 / 0 \mathrm{~V}$ & m/o & $\wedge$ & $\varepsilon \cdot-\varepsilon q$ & \\
\hline & $10 / \wedge \varepsilon$ & $\mid \varepsilon / \Gamma \Lambda$ & 19 & 0. & $0 .-09$ & \\
\hline & $11 / \cdot r$ & $V / T r$ & $9 / 1$ & $r \varepsilon$ & • ل ج و بالاتر. & \\
\hline & \multicolumn{2}{|c|}{$1 \% / r 0 \pm 1 \varepsilon / 17$} & \multicolumn{2}{|c|}{$\varepsilon r / 9 T \pm 11 / 7 \varepsilon$} & انحراف معيار \ميانخين & \\
\hline \multirow{2}{*}{$\begin{array}{l}* * \mathrm{~T}=\cdot / \text { ror } \\
\mathrm{df}=r \mathrm{l} \\
\mathrm{P}=\cdot / \mathrm{VTO}\end{array}$} & $|\varepsilon / 1|$ & $1 r / 7$ & $\varepsilon \pi / V$ & 110 & زن & \multirow[b]{2}{*}{ جنسيت } \\
\hline & $1 \varepsilon / T_{0}$ & $1 T / 9 V$ & $07 / r$ & $1 \varepsilon \wedge$ & مرد & \\
\hline **; $F=r / r V V$ & $10 / 1$ & $1 \% / 10$ & $\varepsilon \cdot / V$ & $1 \cdot v$ & زيردييلم & \multirow{5}{*}{ تحصيلات } \\
\hline \multirow{4}{*}{$P=\cdot / \cdot r q$} & Ir/TO & $1 \cdot / v \varepsilon$ & rᄉ & $1 .$. & دييلم & \\
\hline & $|\varepsilon / 9|$ & $17 / 01$ & $1 N / 7$ & $\varepsilon 9$ & 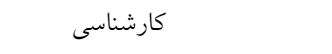 & \\
\hline & $|\varepsilon / 1|$ & $1 r / 7$ & $1 / 0$ & $\varepsilon$ & كارشناسى ارشد & \\
\hline & $1 \varepsilon / T_{0}$ & $1 Y / 9 V$ & $1 / 1$ & $r$ & 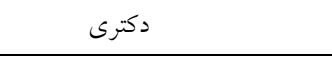 & \\
\hline$* * F=r / \varepsilon 70$ & $|\varepsilon / 0|$ & $1 \% / V$ & $\varepsilon \wedge / \Gamma$ & ITV & ضعيف & \multirow{3}{*}{ وضعيت اقتصادى } \\
\hline \multirow[t]{2}{*}{$\mathrm{P}=\cdot / \cdot r \mu$} & $\mid Y / \wedge 7$ & $11 / 11$ & $\varepsilon\rceil / \wedge$ & irr & متوسط & \\
\hline & 19/rT & TY/rA & $\varepsilon / 9$ & ir & خوب & \\
\hline${ }^{* * *} \mathrm{~F}=\cdot / 91 \varepsilon$ & $\mid r / T \Lambda$ & $1 \cdot / V Y$ & 19 & 0. & مجرد & \multirow{4}{*}{ وضعيت تأهل } \\
\hline \multirow[t]{3}{*}{$\mathrm{P}=\cdot / \varepsilon \mu \varepsilon$} & $1 \varepsilon / \varepsilon \varepsilon$ & $1 \pi / 17$ & vo/r & 191 & 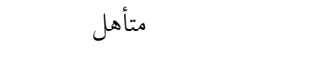 & \\
\hline & $15 / .9$ & $9 / 77$ & $r / r$ & 7 & مطلقه م & \\
\hline & $1 r / 27$ & $17 / Y T$ & $r / \varepsilon$ & 9 & بيوه & \\
\hline \multirow{6}{*}{$* \mathrm{P}=\cdot / \cdots 1$} & $1 r / \Lambda \varepsilon$ & $\Lambda / r o$ & $r / \Lambda$ & 1. & يدر & \multirow{6}{*}{ نسبت با بيمار } \\
\hline & $10 / 41$ & $17 / 11$ & $r / \Lambda$ & 1. & 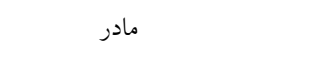 & \\
\hline & $1 \cdot / v 9$ & $N / 9 \varepsilon$ & $O N / Y$ & lor & 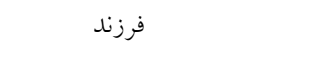 & \\
\hline & $11 / \varepsilon r$ & $1 \cdot / \varepsilon$ & $r T / 1$ & $0 \wedge$ & همسر & \\
\hline & $17 / 01$ & $\mathrm{IV} / \mathrm{TY}$ & $\varepsilon / 9$ & ir & 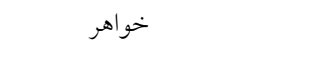 & \\
\hline & $\mid r / \cdot \wedge$ & $I T / M$ & $\mathrm{~V} / \mathrm{r}$ & 19 & برادر & \\
\hline \multirow[t]{3}{*}{$* \mathrm{P}<\cdot / \cdot \cdot 1$} & $1 r / r$ & $9 / 79$ & $\mu$ & $\wedge \vee$ & 1 & \multirow{3}{*}{ سطح ترياز بيمار } \\
\hline & $\mid r / \Lambda \varepsilon$ & N/ro & $m / 0$ & $\wedge$ & r & \\
\hline & $10 / \pi 1$ & $17 / 11$ & $r / 0$ & $\Lambda$ & لم و بيشتر & \\
\hline \multirow[t]{3}{*}{$* \mathrm{P}=\cdot / \wedge 1$} & $1 \varepsilon / \varepsilon r$ & $1 \% / r q$ & $19 / \varepsilon$ & rro & بيمه بايه دارد & \multirow{3}{*}{ وضعيت بيمه بيمار } \\
\hline & $1 . / .9$ & N/^T & $O / V$ & 10 & بيمه بايه ندارد & \\
\hline & $1 r / \cdot 9$ & $10 / V 7$ & $\varepsilon / 9$ & ir & بيمه پايه و مكمل دارد & \\
\hline \multirow{7}{*}{$* \mathrm{P}=\cdot / \cdot \wedge 0$} & $\mid r / T \Lambda$ & $\mid r / \Sigma \Lambda$ & $r 7 / 7$ & v. & نوورولوزى & \multirow{7}{*}{ علت مراجعه } \\
\hline & $10 / 7 \varepsilon$ & 10/Vo & $\varepsilon \varepsilon / q$ & 111 & قلبى عروقى & \\
\hline & $I T / T Y$ & $1 . / 7 r$ & $V / r$ & 19 & ارتويدى & \\
\hline & $1 \cdot / r \varepsilon$ & v & $1 / 9$ & 0 & 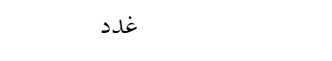 & \\
\hline & $1 T / \varepsilon q$ & $\mathrm{~V} / \mathrm{OV}$ & $0 / r$ & $1 \varepsilon$ & جراحى & \\
\hline & $1 \cdot 109$ & $\wedge$ & $\varepsilon / 9$ & ir & داخلى & \\
\hline & $\mid r / \cdot V$ & $I T / V$ & $9 / 1$ & $r \varepsilon$ & ساير س & \\
\hline
\end{tabular}


علت مراجعه بيماران بود. نسبت سطح ترياز بيماران نيز تقريباً مساوى بود (جدول شماره ()).

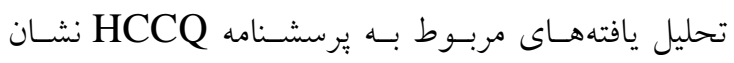

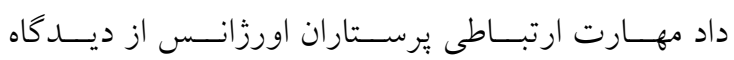

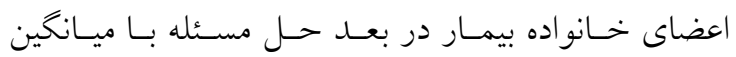

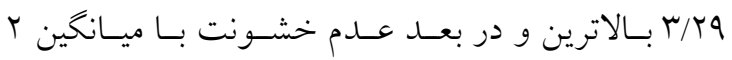

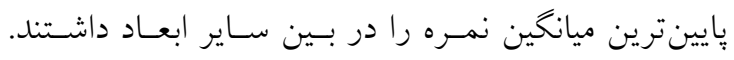
ميانخين نمره مهـارت ارتبـاطى كـل برستـاران نيـز يـايين

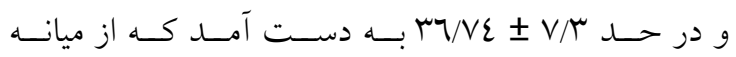
نمره ابزار يعنى ·ع بِايينتر بود (جدول شماره r).
تحمبه درصد از شركت كنندكان مرد و بقيه زن بودند. تحصيلات زير دييلم با V/ •ع درصد بيشترين سطح تحصيلى بين ساير سطوح تحصيلى بود. وضعيت اقتصادى

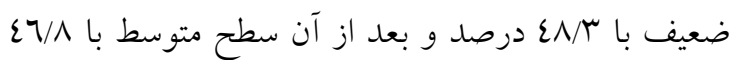
درصد بيشترين فراوانى را داشتند. بيشتر واحدهاى مورد

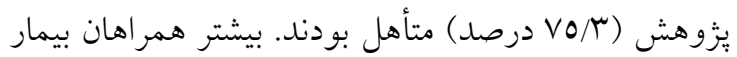

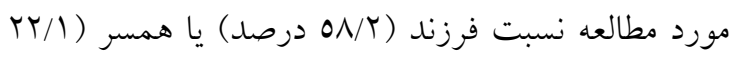
درصد) با بيمار داشتند. ع/19 درصد از بيماران داراى بيمه ڤايه بودند. بيمارى قلبى عروقى با /عـع درصد بيشترين

جدول شماره ז: شاخص هاى عددى مهارتهاى ارتباطى برستاران از ديدكًاه عضو خانوادهى بيماران مراجعه كننده به بخش هاى اورزانس

\begin{tabular}{|c|c|c|c|c|c|c|c|c|}
\hline \multicolumn{4}{|c|}{ مبناى ا تاه } & انحراف & ميانگين & بيشينه & كمينه & مهارتهاى ارتباطى يرستاران و \\
\hline انحراف معيار & ميانگين & بيشينه & كمينه & معيار & & & & حيطههاى آن \\
\hline$\cdot / \wedge \varepsilon$ & $r / r q$ & 0 & 1 & $r / r_{q}$ & $15 / 17$ & $r$. & $\varepsilon$ & حل مسئله (•r-乏) \\
\hline •/Ar & $r / r q$ & 0 & 1 & $r / \mu r$ & $1 \% / .0$ & $r \cdot$ & $\varepsilon$ & احترام (•r-Y) \\
\hline$\cdot / \varepsilon \varepsilon$ & r & $\varepsilon / \pi r$ & 1 & $1 / \pi \varepsilon$ & $7 / \cdot 1$ & ir & $r$ & عدم خشونت (10-r) \\
\hline$\cdot / 10$ & $r / 17$ & 0 & 1 & $\mid / N 1$ & $7 / \mu r$ & 1. & r & رفتار غير كلامى (·-I-Y) \\
\hline .107 & T/AY & $\varepsilon / \varepsilon\rceil$ & $1 / \pi \Lambda$ & $v / r$ & $r\rceil / v \varepsilon$ & $0 \wedge$ & 11 & مهارتهاى ارتباطى (70-سY) \\
\hline
\end{tabular}

نتايج آزمون همبستكى بييرسون نشان داد كه مهارت

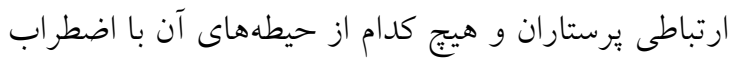

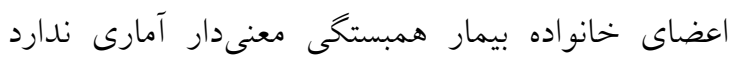
(جدول شماره ع). (جاى )

جدول شماره ع: همبستكى اضطراب عضو خانواده بيماران با

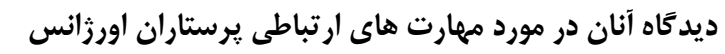

\begin{tabular}{|c|c|}
\hline اضطر ابعضوخانواده & مهارت هاى ار تباطى ير ستار انوحيطه هاى آن \\
\hline $\mathrm{r}=-\cdot \cdot / \cdot 0$ & حل مسئله \\
\hline \multicolumn{2}{|l|}{$\mathrm{P}=\cdot / \varepsilon / V$} \\
\hline$r=-\cdot / \cdot \varepsilon r$ & 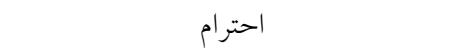 \\
\hline \multicolumn{2}{|l|}{$P=\cdot / \varepsilon q \varepsilon$} \\
\hline$r=-. / .01$ & 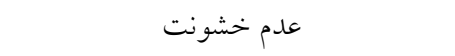 \\
\hline \multicolumn{2}{|l|}{$\mathrm{P}=\cdot / r \varepsilon 7$} \\
\hline$r=-. / . r 7$ & رفتار غير كلامى \\
\hline \multicolumn{2}{|l|}{$\mathrm{P}=\cdot 1070$} \\
\hline$r=-. / .02$ & مهارت هاى ارتباطى \\
\hline $\mathrm{P}=\cdot / r \wedge \uparrow$ & \\
\hline
\end{tabular}

تحليــل يافتـهـهــاى مربـوط بـهـ يرسشــامه اضـطر اب

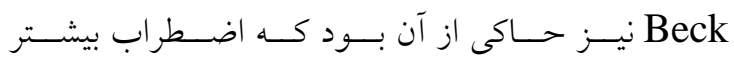

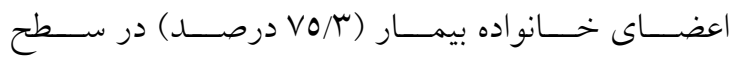
خفيف بود. نزديك بـه ل1 ا درصـــ اعضـاى خـانواده نيـز

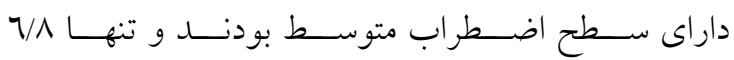

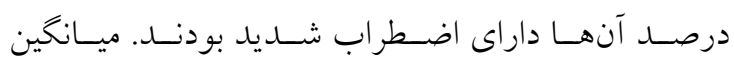

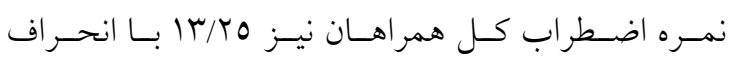

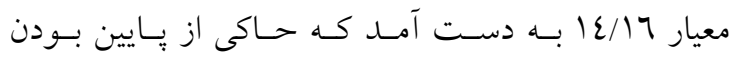
سطح كلى اضطراب در آنها بود (جدول شماره r).

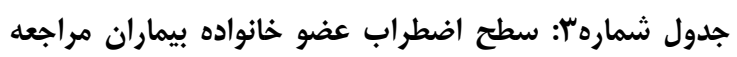

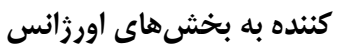

\begin{tabular}{|c|c|c|}
\hline درصد & فراوانى & اضطراب عضو خانواده \\
\hline volr & 191 & خفيف (كمتر از Tr) \\
\hline $1 V / 9$ & ¿1 & متوسط (YY-ro) \\
\hline $7 / 1$ & 11 & شديد (بالاى ro) \\
\hline $1 .$. & זרז & جمع كل كل \\
\hline \multicolumn{2}{|c|}{$1 \% / r 0 \pm 1 \varepsilon / 17$} & انحراف معيار £ميانكين \\
\hline & r & بيشينه-كمينه \\
\hline
\end{tabular}


رضايت داشتند (ع). همخنين، نتايج يزوهش حاضر با مطالعه

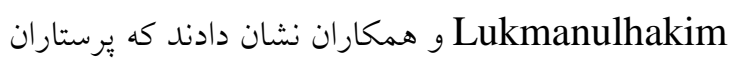

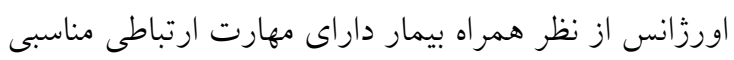
بودند به نحوى كه اضطراب همر اه بيمار را كاهش دادند (1).

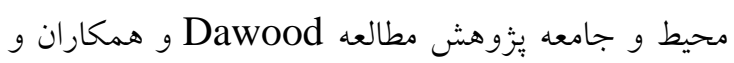

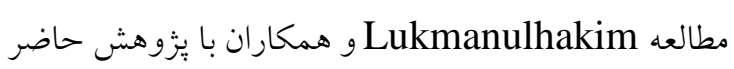
متفاوت بود. در مقابل، نتايج يزوهش حاضر با مطالعه همانه

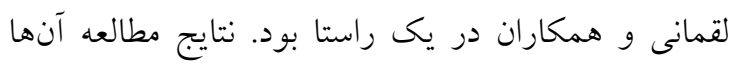

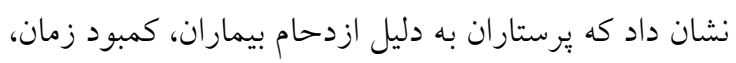
افزايش فشار كارى، مشكلات معيشتى و محيط كار در

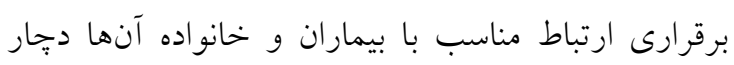

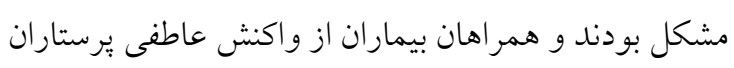

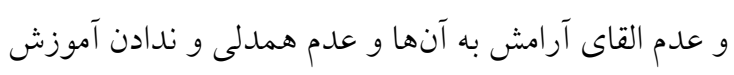

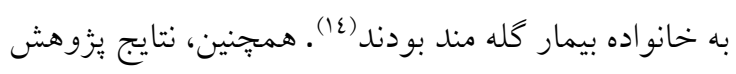

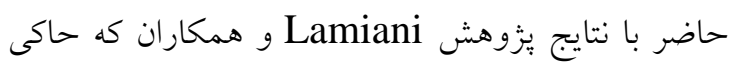
از وجود ضعف در زمينه برقرارى ارتباط برستار با بيمار

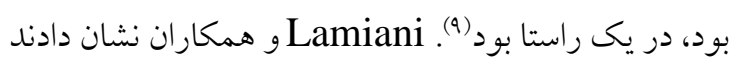

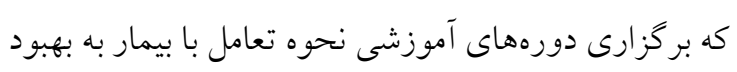

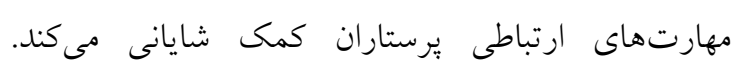

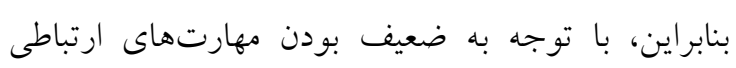

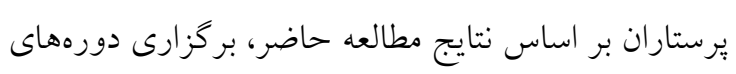

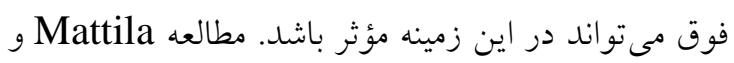

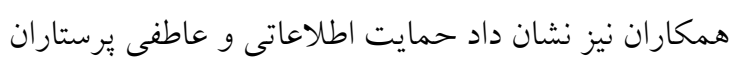

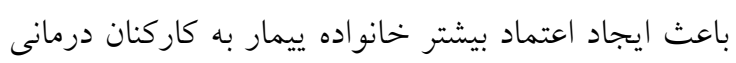
و شيوه مراقبت آنها از بيمارشان مى خردد (10). نتايج

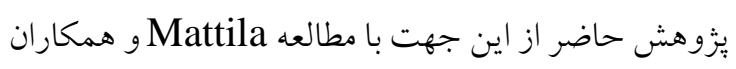

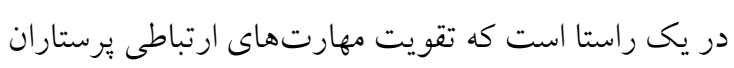
با بيمار و همر اهان آن ها مىتواند نتايج مثبتى را به همراه داشته باشد.

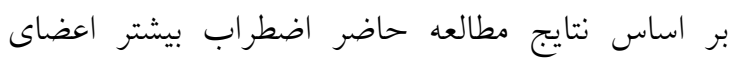

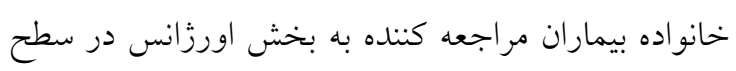
خفيف بود. Lukmanulhakim و همكاران نشان دادند اغلب اعضاى خانواده بيمار سطوح متوسط و وِيايين اضطراب را در بخش اورزانس تجربه كردند كه تا حدى با باليا
تحليل اضطراب اعضاى خانواده بيمار بر اساس ويزگى

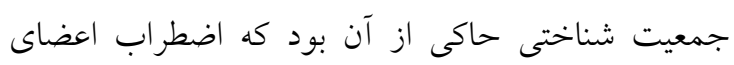

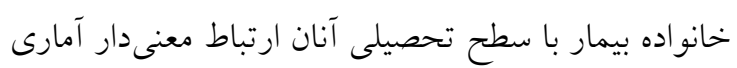

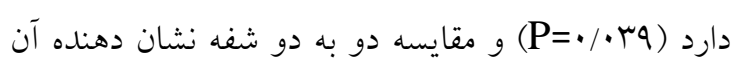
بود كه اضطراب اعضاى خانواده بيماران با تحصيلات دانشخاهى به طور معنى دارى بالاتر از اعضاى خانو اده

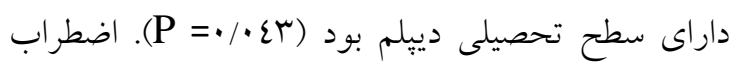

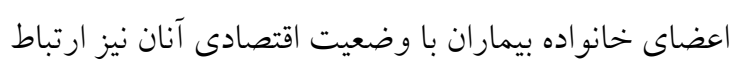

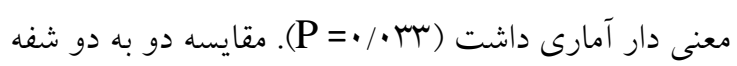

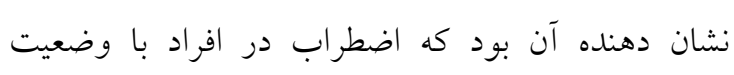

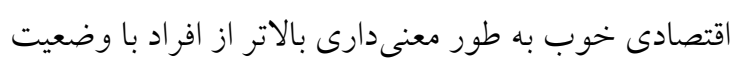

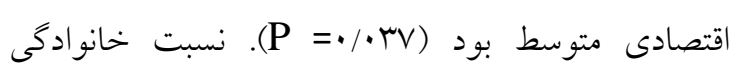

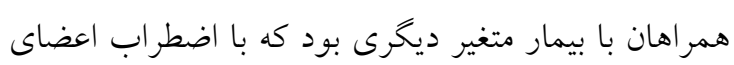

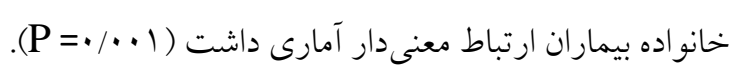

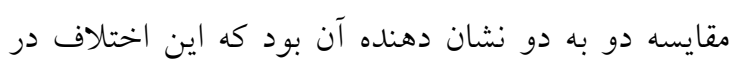

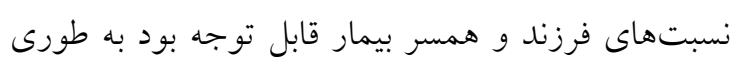

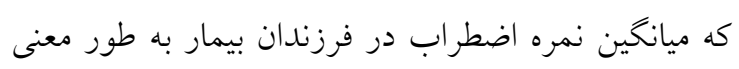

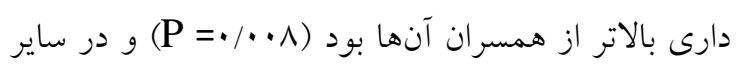
سطوح نسبتهاى خانوادگى اين اختلاف معنى دار نبود.

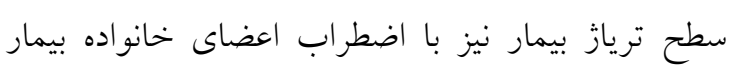

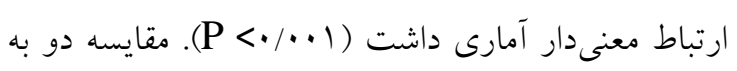

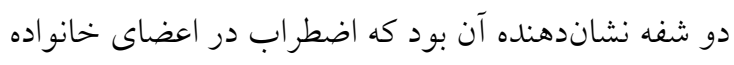

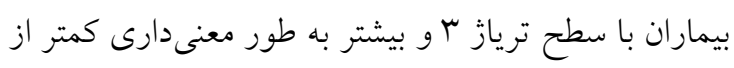

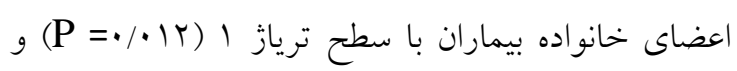

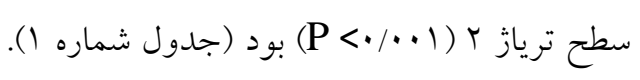

\section{بحث و نتيجه تيرى}

با توجه به نتايج مطالعه، مهارت ارتباطي ئرى برستاران از ديدكاه

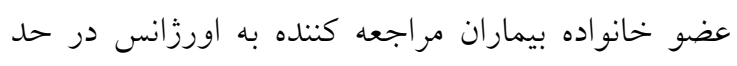

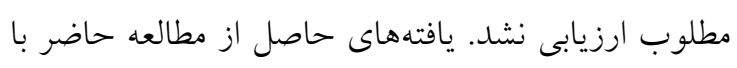

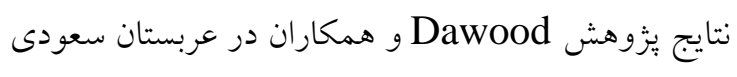

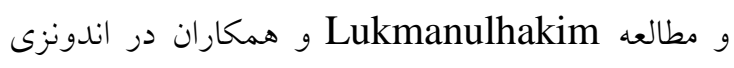
همسو نبود. Dawood و همكاران نشان دادند همراهان بيماران از نحوه برقرارى ارتباط صحيح يرستاران با خود همدان ندان همران 
هستند و همراهان بيمار با ديدن بيمار خود در شرايط تهلديد كننده حيات، سطح اضطراب بالايى را تجربه مى كنند.

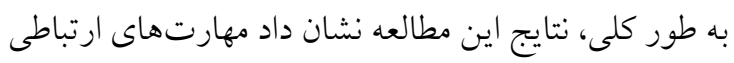

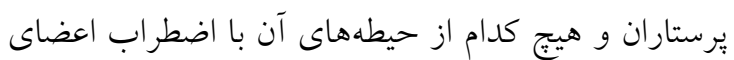
خانواده بيمار همبستكى معنىدار آمارى نداشت. نتايج مطالعه حاضر از اين لحاظ با مطالعه ايمانى بور و همكاران كه اثربخشى حمايت اطلاعاتى مراقبان خانوادكى بيماران تحت عمل جراحى قلب باز بر اضطراب آنان را بررسى

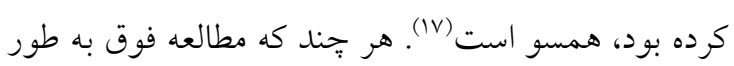
مستقيم رابطه بين مهارتهاى ارتباطى يرستاران را با اضطراب اعضاى خانواده بيمار مورد بررسى قرار نداده بود ولى حمايت اطلاعاتى مراقبان خانو ادگى بيماران را مىتوان بخشى از مهارتهاى ارتباطى يرستاران محسوب كرد. همجنين، نتايج يُزوهش حاضر با نتايج مطالعه فلاحى خشكناب و همكاران كه نشان دادند مشاوره يرستارى بر كاهش اضطراب خانواده بيماران بسترى در بخش مراقبت هاى ويزٔه جراحى قلب مؤثر است، همسو نبود (17.) تمركز يزووهش فلاحى خشكناب و همكاران بر روى تأثير مشاوره يرستارى بر كاهش اضطراب خانواده بيماران بسترى بود.

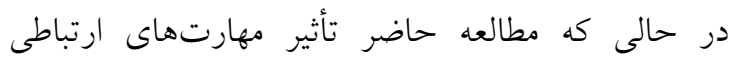
يرستاران بر روى كاهش اضطر اب خانواده بيمار ان اورزانس را بررسى نمود. از طرف ديخر مهارتهاى ارتباطى يرستاران مىتواند در مشاوره يرستارى نيز تجلى بيدا كند و از اين جهت نتايج يزوهش حاضر با مطالعه آنها قابل مقايسه است. هم:جنين، نتايج مطالعه جباريور و همكاران كه نشان دادند اطلاع رسانى از وضعيت بيمار و آكاهى مهى خانواده از وضعيت بيمار به طور معنىدارى باعث كاهش اضطراب اعضاى خانواده بيمار مىشود، با نتايج اين يُزوهش همسو نبود(·r). مطالعه فوق نيز به طور مستقيم رابطه بين مهارتهاى ارتباطى يرستاران را با اضطراب

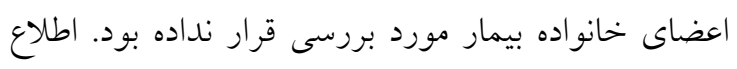
رسانى از وضعيت بيمار تنها مىتواند بخش كوجكى از

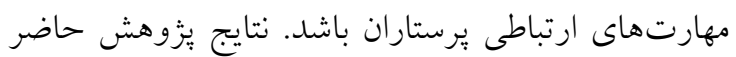

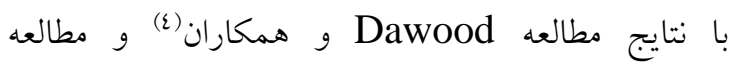

نتايج مطالعه حاضر همسو است (1) Dawood و همكاران نيز نشان دادند اعضاى خانواده بيماران در بخش اورزانس سطوح استرس و افسردگى بالايى داشتند كه با نتايج اين

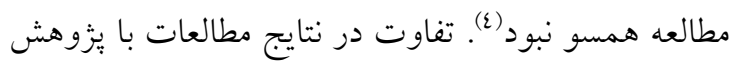
حاضر مىتواند به تفاوت در محيط و جامعه يزوهش مرتبط باشد. همجنين، مطالعات فوق بيان نكردند در جّه مرحله اى از مراجعه بيماران به اورزانس اقدام به توزيع و كردآورى يرسشنامهها كردند ولى در خصوص مطالعه حاضر، به دليل فراهم نبودن شرايط براى كردآورى برى اطلاعات در محيط اورزانس، يرسشنامها بعد از انتقال بيمار به بخش تكميل شدند كه يكى از دلايل يايين بودن سطح اضطراب همر اهان بيمار در مطالعه حاضر مى تواند به همين دليل باشد كه اضطراب همر اهان بيمار يس از تعيين تكليف و درمانهاى اوليه ممكن و انتقال به بخش تا حدى فرو كش كرده باشد.

فلاحى خشكناب و و همكاران(17) و ايمانى يور و و باند همكاران(IV) نيز نشان دادند اضطراب خفيف و متوسط شايعترين ياسخ روان شناختى اعضاى خانواده بيماران بسترى در بخش مراقبت ويزه قلب بود، كه با نتايج يزوهش حاضر تا حدى در يك راستا مىباشد. Pochard و همكاران(11) و سياهكلى و همكاران(19) نيز نشان دادند خانو اده بيماران بخش مراقبتهاى ويثزه داراى نشانههايى از اضطراب بودند كه با نتايج يزوهش حاضر تا حدى همسو مىباشد. هر دو مطالعه فوق در بخش مراقبتهاى

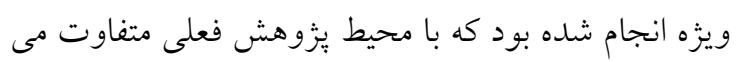
باشد. همجينين مطالعات فوق، شدت اضطراب همراهان بيمار را گزارش ندادند. اما نتايج يزوهش حاضر با نتايج مطالعه زارعى و همكاران كه نشان دادند اغلب اعضاى خانواده بيمار ان بخش مر اقبت هاى ويزه اضطر اب و استرس

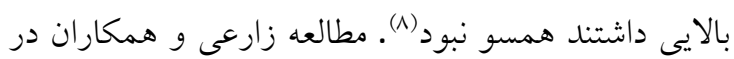
بخش مراقبتهاى ويزه انجام شده كه با شرايط مطالعه حاضر كه در بخش اورزانس انجام شد، متفاوت است. بيماران بخش مراقبتهاى ويزه اغلب در شرايط حادترى 
خدمت و يا ساير مكانيسمهاى تشويقى به منظور افزايش

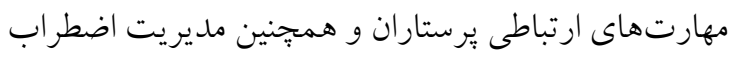

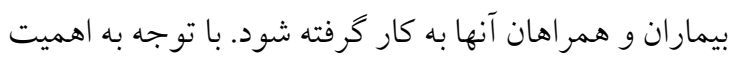

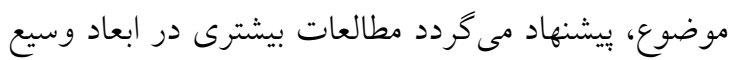

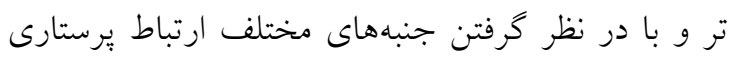

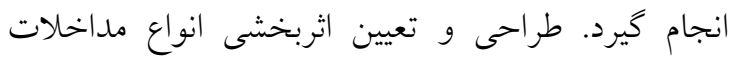

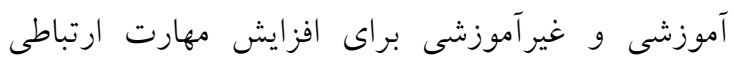

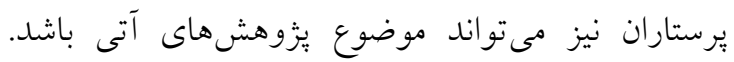

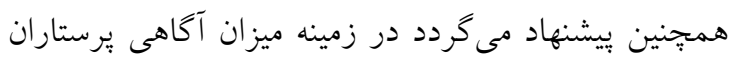
در مورد مهارتهاى ارتباطى مطالعات بيشترى انجام گيرد.

تعارض منافع: هيج گونه تعارض منافع توسط نويسندگان

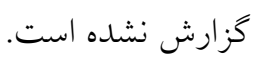

\section{تقدير و تشكر}

مطالعه حاضر حاصل پِيان نامه دانشجويى با كد اخلاق IR.IUMS.REC.1397.1323 دانشخاه علوم يزشكى ايران حمايت شده است. تيم

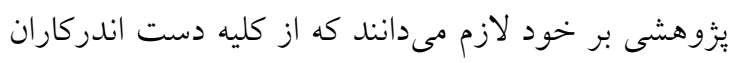

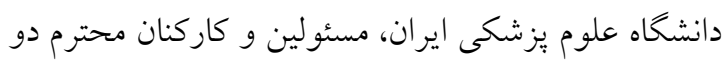
مركز آموزشى درمانى منتخب وابسته به دانشخاه علوم يزشكى ايران به ويزه كاركنان محترم بخش اورزانس و و خانوادههاى شركت كننده كه بلدون همكارى آنها انجام اين مطالعه ممكن نبود، تشكر و قدردانى نمايند.
Lukmanulhakim و همكاران(1) كه نشان داده بودند نحوه برقرارى ارتباط يرستاران با سطوح اضطر اب همر اهان

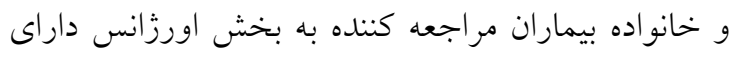

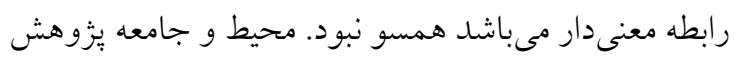
مطالعات فوق نيز با مطالعه حاضر متفاوت بود. بر اساس يافتهاى اين يزوهش بيشتر اعضاى خانواده

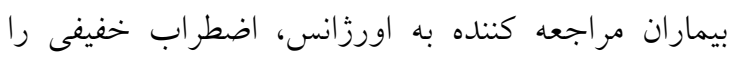

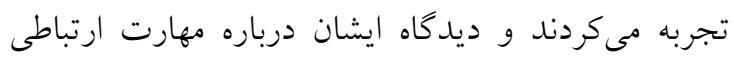

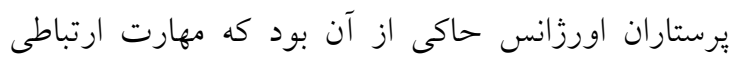

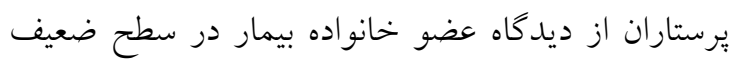

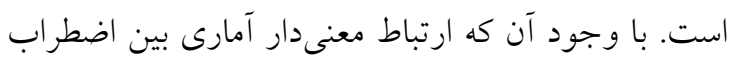

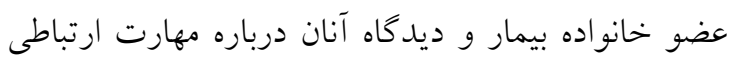
يرستاران در اين مطالعه يافت نشد، به نظر مى درسد ضعديف

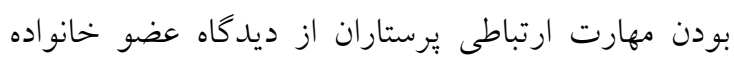

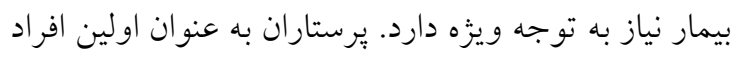

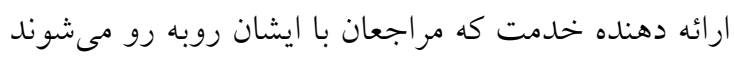
تعيين كننده تصويرى هستند كه در ذهن عضو خانو اده بيمار از خدمات مراقبت درمانى ايجاد مىشود. بنابر اين با توجه

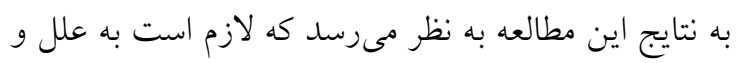

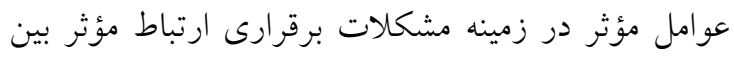

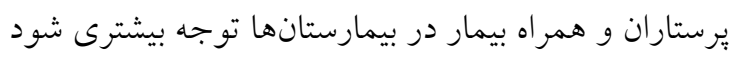

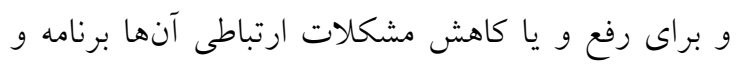

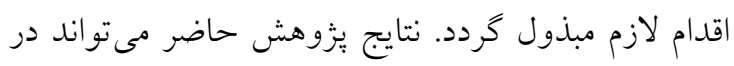

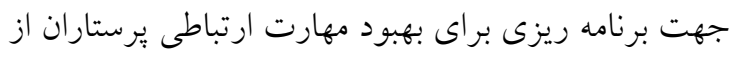

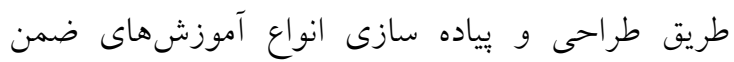

\section{References}

1. Lukmanulhakim S, Anna A. The relationship between communication of nurses and level of anxiety of patient's family in emergency room dr. Dradjat Prawiranegara hospital, Serang Banten, Indonesia. Int J Res Med Sci. 2016;4(12):5456-62.

2. Ramazankhani A, Marzban S, Naghibzadeh-Tahami A, Sarani A. Assessing waiting time patients in emergency ward of Kerman University of Medical Sciences. Journal of Health Promotion Management. 2016 15;5(2):20-30. [Persian]

3. Wiman E, Wikblad K. Caring and uncaring encounters in nursing in an emergency department. $J$ Clin Nurs. 2004;13(4):422-9.

4. Dawood E, Misuta R, Alharbi M, Almurairi A, Kanori H, Alsaiari M, et al. Relationship between Nurses' Communication and Levels of Anxiety and Depression among Patient's Family in the Emergency Department. Ann Psychiatry Ment Health. 2018;6(1):1125. 
5. Starmer AJ, Spector ND, Srivastava R, West DC, Rosenbluth G, Allen AD, Noble EL, Tse LL, Dalal AK, Keohane CA, Lipsitz SR. Changes in medical errors after implementation of a handoff program. New England Journal of Medicine. 2014 6;371(19):1803-12.

6. Hosieni F, Ravari A, Akbari A. The Effect of Communicating with Patients Using Peplau Model on Patients' Satisfaction with the Provided Nursing Cares at the Cardiac Intensive Care Unit. Iran Journal of Nursing. 2017;29(104):36-45. [Persian]

7. Townsend MC, Morgan KI. Psychiatric mental health nursing: Concepts of care in evidence-based practice. FA Davis; 2017 Oct 19.

8. Zarei M, Keyvan M, Hashemizadeh H. Assessing the Level of Stress and Anxiety in Family Members of Patients Hospitalized in the Special Care Units. Int. J. Rev. Life. Sci. 2015;5(11):11822.

9. Lamiani G, Furey A. Teaching nurses how to teach: An evaluation of a workshop on patient education. Patient Educ Couns. 2009;75(2):270-3.

10. Gremigni P, Sommaruga M, Peltenburg M. Validation of the Health Care Communication Questionnaire (HCCQ) to measure outpatients' experience of communication with hospital staff. Patient Educ Couns. 2008;71(1):57-64.

11. Costa CL, Sánchez RG, González ST, Marín JR, van-der Hofstadt Roman CJ. Psychometric properties of the Spanish adaptation of the health care communication questionnaire (HCCQ). Span J Psychol. 2015;18.

12. Beck AT, Epstein N, Brown G, Steer RA. An inventory for measuring clinical anxiety: psychometric properties. J Consult Clin Psychol. 1988;56(6):893.

13. Khesht-Masjedi MF, Omar Z, Masoleh SM. Psychometrics properties of the Persian version of Beck Anxiety Inventory in North of Iranian adolescents. International Journal of Educational and Psychological Researches. 2015;1(2):145.

14. Loghmani L, Borhani F, Abbaszadeh A. Factors affecting the nurse-patients' family communication in intensive care unit of kerman: a qualitative study. J Caring Sci. 2014;3(1):67-82 .[Persian]

15. Mattila E, Kaunonen M, Aalto P, Åstedt-Kurki P. The method of nursing support in hospital and patients' and family members' experiences of the effectiveness of the support. Scand J Caring Sci. 2014;28(2):305-14.

16. Fallahi KM, Farzadmehr M, Hosseini MA, Khankeh H, Noorabadi Z. Nursing Consultation on Anxiety of Patient's Family in Cardiac Surgery Intensive Care Unit. Journal of Research Development in Nursing \& Midwifery. 2016;12(3):1-8. [Persian]

17. Imanipour M, Heidari Z, Seyedfatemi N, Haghani H. Effectiveness of informational support on anxiety among family carers of patients undergone open heart surgery. Journal of hayat. 2012;18(3):33-43. [Persian]

18. Pochard F, Darmon M, Fassier T, Bollaert PE, Cheval C, Coloigner M, Merouani A, Moulront S, Pigne E, Pingat J, Zahar JR. Symptoms of anxiety and depression in family members of intensive care unit patients before discharge or death. A prospective multicenter study. J Crit Care. 2005;20(1):90-6.

19. Rabie Siahkali S, Khalegh Doost Mohamadi T, Paryad E, Atrkar Roshan Z. Family and anxiety in intensive care units. J Holist Nurs Midwifery 2007, 17(2): 1-8. [Persian]

20. Jabbarpour M, Abdoli F, Kazemi M. The effect of providing information about the patient's condition on the anxiety level of the family members of hospitalized patients with traumatic brain injury. Journal of hayat. 2018;1:127-39. [Persian] 